\title{
Comparison of 8 Different Colorimetric, Radiochemical and Immunological Procedures for the Determination of Iron Binding Capacity
}

\author{
By R. Haeckel, H. Haindl, E. Hultsch, P. Mariss and M. Oellerich \\ Technical Assistance: C. Weidemann, M. Puff, I. Dietertch, H. Körber \\ Institut fïr Klinische Chemie, Institut fïr Nuklearmedizin und Department fïr Biometrie, Medizinische Hochscbule Hannover
}

(Eingegangen am 22. August/29. Oktober 1973)

\begin{abstract}
Two radiochemical (Irosorb 59 and Res-O-Mat $\mathrm{Fc}^{59}$ ), a mechanized (DSA 560) and several manual colorimetric procedures (test combination of Roche, Merck and Haury) for the determination of the total iron binding capacity werc compared with the transferrin-binding capacity (immunoprecipitation). Whereas all methods show a satisfactory correlation with the transferrin concentration, most colorimetric procedures lead to higher values, while the Merckotest leads to lower values for the total iron binding capacity. In some control sera the total iton binding capacity is overestimated by several colorimetric methods, which are also subject to interference by hemoglobin. All other procedures arc unaffected by hemolysis. With the mechanization of procedures for immunoprecipitation, these methods are now to be preferred.
\end{abstract}

Zwei radiochemische (Irosorb 59 und Res-O-Mat Fe ${ }^{59}$ ), ein mechanisiertes (DSA 560) und verschiedene manuelle kolorimetrische Verfahren (Testkombination von Roche, Merck und Haury) zur Bestimmung der totalen Eisenbindungskapazität werden mit der Transferrin-Bindungskapazität (Immunopräzipitation) verglichen. Während alle Methoden mit der Transferrin-Konzentration ausreichend korrelieren, führen die meisten kolorimetrischen Verfahren zu höheren und der Merckotest zu nicdrigeren Werten für die totale Eisenbindungskapazität. In einigen Kontrollseren wird die totale Eisenbindungskapazität mit verschiedenen kolorimetrischen Methoden zu hoch gefunden. Die selben werden durch Hämoglobin gestört. Alle anderen Verfahren werden durch Hämolyse nicht beeinflußt. Mit der Einführung von mechanisierten Verfahren zur immunologischen Transferrin-Bestimmung sollte diese Methode bevorzugt werden.

The total iron binding capacity of human serum is considered to be a useful estimation of its transferrin concentration. However, recent investigations by various authors $(1-3)$, have shown, that in addition to transferrin, other serum proteins are able to bind a small quantity of iron ions. Therefore, the total iron binding capacity is expected to exceed the transferrin iron binding capacity if iron is added under saturating conditions. In the following, this assumption was investigated with various procedures for the determination of the total iron binding capacity in human sera.

Usually one third of the iron binding capacity of serum is loaded with iron. After the addition of labelled iron, the latent iron binding capacity ${ }^{1}$ ) can be calculated from the ratio of bound to added ${ }^{59} \mathrm{Fe}$. This is measured after all free ions have been separated from the incubation medium by ion exchange materials, such as the Res-OMat strip (Byk-Mallinckrodt) or resin sponges (Abbott). The same procedure can be applied for the determination of total iron binding capacity if the serum is depleted of all iron ions. This is achieved by lowering the $\mathrm{pH}$ value of the incubation medium and by binding all free iron ions to an Amberlite powder. After centrifugation the supernatant consists of iron free serum which can be used for the determination of the iron binding capacity as described above (Byk-Mallinckrodt).

Two colorimetric procedures (Merckotest, ferrozine method) also measure the latent iron binding capacity,

1) Total iron binding capacity $(\mu \mathrm{mol} / 1)=$ latent iron binding capacity $(\mu \mathrm{mol} / \mathrm{l})+$ serum iron concentration $(\mu \mathrm{mol} / \mathrm{l})$. but, by the ratio of unbound to added unlabelled Fe. Under these conditions free and protein-bound iron must not be separated because only free $\mathrm{Fe}^{3+}$ ions react with the chromogens bathophenanthroline and ferrozine.

Three other bathophenanthroline procedures (Roche diagnostica, Haury, DSA 560) are included in these comparative studies. After the addition of unlabelled $\mathrm{Fe}^{3+}$ all free iron ions are bound to $\mathrm{MgCO}_{3}$ which is separated from the incubation medium by centrifugation. The supernatant is used for the usual determination of the iron concentration, which now indicates the total iron binding capacity.

\section{Materials and Methods}

Materials and instruments were used as listed on Table 1 or as reported recently (4).

Reagents for the ferrozine method were a generous gift of Dr. R. Helger (E. Merck, D-61 Darmstadt); reagents for the Res-O-Mat method were kindly given by Byk-Mallinckrodt Chemische Produkte GmbH (D-6051 Dietzenbach); and reagents for the Irosorb method were a gift from Deutsche Abbott GmbH (D-6507 Ingelheim).

The iron concentration was determined with a Beckman DSA 560 analyzer (4). This value was added to the unbound (or free) iron binding capacity in the radiochemical and the Merckotest procedures.

The transferrin concentration was determined either directly by a radial immunodiffusion technique using Partigen plates (4) or indirectly measuring the amount of iron bound to the protein. 1 Mole transferrin binds $2 \mathrm{Fe}^{3+}$ ions. Since the molecular weight of transferrin is approx. 89000 (5), the concentration of trans- 
ferrin in $\mathrm{mg} / 100 \mathrm{ml}$ is multiplied by 0.2247 to get the transferriniron binding capacity in $\mu \mathrm{mol} / \mathrm{l}$.

All colorimetric procedures used for these comparative studies cmploy bathophenanthroline as the chromogen, with the exception of the ferrozinc method (6). The DSA-method for the determination of the total iron binding capacity was recently described in detail (4). Values listed under Haury, Roche and Mcrckotest were obtained by strictly following the recommendations of the manufacturer (Tab. 1) of the corresponding reagent kits. The radiochemical methods differ in the step at wich free and protein-bound iron ions are separated from each other.

Res-O-Mat $\mathrm{Fe}^{59}$ : The Res-O-Mat strip extracts all free $\mathrm{Fe}^{3+}$ from the incubation medium. The counts per minute before (precounts) and after (post-counts) this step are measured. The latent iron bindung capacity $(\mu \mathrm{g} / 100 \mathrm{ml})$ is calculated by multiplying a factor $F$ (iron content of the vial in $\mu \mathrm{g} \times 200$ ) with the ratio postcounts/pre-counts.

Irosorb-59: A resin sponge binds all free iron ions. The incubation medium which contains the protein-bound iron fraction is aspirated out of the vial. The sponge remaining in the vial is rinsed three times with double distilled water. The latent iron binding capacity is calculated as follows:

$$
\mu \mathrm{g} / 100 \mathrm{ml}=\left(1-\frac{\text { post-counts per minute }}{\text { pre-counts per minute }} \cdot \mathrm{L}\right) \cdot \mathrm{F} .
$$

( $F=$ the amount of iron added to the incubation vial in $\mu \mathrm{g} / \mathrm{ml}$ $\times 100$.)

$\mathrm{L}$ is a correction factor specific for each reagent kit lot which is supplied by the manufacturer.

The conversion factor from $\mu \mathrm{g} / 100 \mathrm{ml}$ iron to $\mu \mathrm{mol} / \mathrm{l}$ is 0.1791 . All solutions are prepared with deionized and quarz distilled water (approx. $0.5 \mu \mathrm{S}$ ). For all methods plastic materials were used if possible. The glassware is washed in a standard machine, then soaked in concentrated $\mathrm{HCl}$ and rinsed carefully with double distilled $\mathrm{H}_{2} \mathrm{O}$.

For the investigation of the bemoglobin interference 3 samples were prepared:

I. $9 \mathrm{ml}$ serum $+1 \mathrm{ml}$ hemoglobin solution,

II. $9 \mathrm{ml}$ serum $+1 \mathrm{ml} 9 \mathrm{~g} / \mathrm{l} \mathrm{NaCl}$ and

III. $9 \mathrm{ml} 9 \mathrm{~g} / \mathrm{l} \mathrm{NaCl}+1 \mathrm{ml}$ hemoglobin solution. The hemoglobin solution was prepared according to LEHMANN and HuNTsIrAN (7). After the preparation, the hemoglobin content was measured by a cyan-methemoglobin method (8).

\section{Statistical Analysis}

The precision from day-to-day for the determination of the iron binding capacity in control sera was estimated as recently described (4). The variance of reproduction (precision within-series) was calculated as follows

$$
\mathrm{s}^{2}=\frac{1}{2 \mathrm{~N}} \sum_{\mathrm{i}=1}^{\mathrm{N}}\left(\mathrm{y}_{11}-\mathrm{y}_{\mathrm{i} 2}\right)^{2} ;
$$

coefficient of variation $(C V)=s / \bar{y} \cdot 100(\%)$. The total variance (Var) of any method (sample $i$ yields the values $y_{i j} ; j=1,2$ ) was determined by the following equation

$$
\operatorname{var}=\frac{1}{2 \mathrm{~N}-1} \sum_{i=1}^{N} \sum_{j=1}^{2}\left(\mathrm{y}_{i j}-\bar{y}\right)^{2} .
$$

The standardized variance (SV $=\mathrm{s}^{2} /$ var. $100 \%$ ) indicates the percentage of $\mathrm{s}^{2}$ on the total variance (Haindr, H., Mariss, P. \& Huntsch, E., unpublišbed work).

All procedures were compared with the reference method $\left(x_{i j}\right.$ values; $\mathfrak{j}=1.2)$ : the differences were significant in all cases as judged by a two-way layout analysis. When systematic analytical errors are inherent to the methods applied the equation for the regression line can be written

$$
y_{i j}=a+b x_{i}+e_{i}+f_{j} .
$$

$e_{i}$ indicates the error about the regression introduced by intersample variation of interfering substances and $f_{j}$ the error caused by the analytical vatiability (preçision within-series). Assuming that both errors are independent of each other, the total variance about regression can be split into the variance of reproduction $\left(\operatorname{var}\left(f_{J}\right)=s^{2}\right.$ ) and the intersample variance about the regression $\operatorname{var}\left(e_{1}\right)$. To compare var $\left(e_{i}\right)$ between the various methods the coefficient of variation $\left(\mathrm{CV}^{*}\right)$ is preferrred.

\section{Results and Discussion .}

\section{Precision}

The precision from-day-to-day of the methods applied was determined with commercial control sera (Tab. 2) and found comparable for all procedures. The precision within-series (reproducibility) was calculated for each method from duplicate determinations. For comparing the precision between the various methods the coefficient of variation (CV) and especially the standardized variance, which is invariant against linear transformations, should be considered (Tab. 3). The reference method (I) yielded the best precision, method III a larger and all other procedures almost the same variance with human sera.

\section{Accuracy, correlation between metbods}

The mean value for the total iron binding capacity varied considerably between the methods used for these studies. This effect can be partly attributed to different concentrations of iron ions in the iron binding reagent (Tab. 1).

In a preceeding communication (4) we have reported that with increasing iron concentration the binding capacity of human sera for these ions is reached at approx. $90 \mu \mathrm{mol} / \mathrm{l}$. With higher concentrations, a plateau is observed rising more or less slightly. Above approx. $300 \mu \mathrm{mol} / 1 \mathrm{Fe}^{3+}$ the iron binding capacity starts to increase further with the iron concentration.

The saturation curves of the iron binding capacity for commercially available control sera (Fig. 1) either resemble those for human sera (Behring control sera) or differ significantly concerning the formation of a plateau (Hyland, Seronorm, Monitrol). The behaviour of some control sera may also vary with the lot as demonstrated for Monitrol (Fig. 1B). In the absence of a plateau, the value of the iron binding capacity strongly depends on the iron concentration of the binding reagent. Therefore, the mean values from all methods differ much more with some control sera (Fig. 1: Seronorm, Hyland) than with human sera (Tab. 3). Transferrin cannot be determined by immunoprecipitation in Seronorm which is based on horse serum.

The transferrin-iron binding capacity determined by an immunological method was used as reference value $(2,3)$ during these investigations. Some methods yielded higher and one method lower values (Merckotest) than the reference procedure.

Since other proteins besides transferrin are known to bind $\mathrm{Fe}^{3+}(1-3)$, indirect methods using saturating iron concentrations must lead values for the total iron binding capacity that are higher than the true transferrin concentration. The methods whose values are 
Tab. 1

Assay conditions for the determination of the iron binding capacity

\begin{tabular}{|c|c|c|c|c|c|c|c|c|}
\hline \multirow[t]{2}{*}{ Method } & \multicolumn{4}{|c|}{$\begin{array}{c}\text { Assay for saturation of serum samples } \\
\text { with } \mathrm{Fe}^{\mathrm{s}+}\end{array}$} & \multicolumn{4}{|c|}{ Assay for determination of the iron concentration } \\
\hline & $\underset{\mu \mathrm{mnol} / 1}{\mathrm{Fe}^{3+}}$ & $\begin{array}{l}\text { Sample } \\
\mathrm{ml}\end{array}$ & $\begin{array}{c}\mathrm{FeCl}_{2} \\
\mathrm{ml}\end{array}$ & $\begin{array}{l}\text { Butfer, mol/l } \\
(\mathrm{pH})\end{array}$ & $\begin{array}{l}\text { Reducing } \\
\text { reagent } \\
\text { mmol/1 }\end{array}$ & $\begin{array}{l}\text { Color } \\
\text { reagent } \\
\text { mmol/1 }\end{array}$ & $\begin{array}{l}\text { Buffer } \\
\text { (pH) }\end{array}$ & Photometer \\
\hline $\begin{array}{l}\text { DSA } 560 \\
\text { (Merckotest Nr. 3307)' }\end{array}$ & 92.5 & 0.2 & 0.2 & - & $\begin{array}{c}\text { ascorbate } \\
7.0\end{array}$ & $\begin{array}{c}\text { bathophenan- } \\
\text { throline } \\
0.11\end{array}$ & $\begin{array}{c}\text { phosphate (5.5) } \\
0.1 \mathrm{mmol} / 1\end{array}$ & $\begin{array}{c}\text { DSA } 560(530 \mathrm{~nm}) \\
\text { (Beckman Instruments) }\end{array}$ \\
\hline $\begin{array}{l}\text { Roche Diagnostica") } \\
\text { (Eisenbindungskapazität) }\end{array}$ & 60.0 & 0.5 & 1.0 & - & $\begin{array}{l}\text { dithionite } \\
43.0\end{array}$ & $\begin{array}{c}\text { bathophenan- } \\
\text { throline } \\
0.3\end{array}$ & ? & Eppendorf $1101(546 \mathrm{~nm})$ \\
\hline $\begin{array}{l}\text { Merckotest } \\
\text { (Artikel Nr. 3313) }^{\text {) }}\end{array}$ & 55.95 & 0.5 & 0.1 & $\begin{array}{c}\text { Tris } 0.294 \\
\text { (8.5) }\end{array}$ & $\begin{array}{c}\text { methylamino- } \\
\text { phenolsulfite } \\
2.8 \\
\mathrm{NaHSO}_{2} \\
15.0\end{array}$ & $\begin{array}{c}\text { bathophenan- } \\
\text { throline's) } \\
0.16\end{array}$ & $\begin{array}{c}\text { Tris (7.8) } \\
238 \mathrm{mmol} / \mathrm{l}\end{array}$ & Eppendorf $1101(546 \mathrm{~nm})$ \\
\hline $\begin{array}{l}\text { Ferrozine method } \\
\text { (Reagents: E. Merck) }^{2} \text { ) }\end{array}$ & 36.9 & 0.5 & 0.2 & $\begin{array}{c}\text { Tris } 0.294 \\
(7.8)\end{array}$ & $\begin{array}{c}\text { ascorbate } \\
13.0\end{array}$ & $\begin{array}{c}\text { ferrozine') } \\
263 \mathrm{mg} / \mathrm{l}\end{array}$ & $\begin{array}{c}\text { Tris (7.8) } \\
263 \mathrm{mmol} / 1\end{array}$ & Eppendorf $1101(546 \mathrm{~nm})$ \\
\hline $\begin{array}{l}\text { Haury } \\
\text { (Serum-Eisentest) }^{3} \text { ) }\end{array}$ & 59.7 & 0.6 & 0.2 & - & $\begin{array}{c}\text { ascorbate } \\
15.0\end{array}$ & $\begin{array}{c}\text { bathophenan- } \\
\text { throline }) \\
0.26\end{array}$ & $?$ & Eppendorf $1101(546 \mathrm{~nm})$ \\
\hline $\begin{array}{l}\text { Irosorb-59 } \\
\text { (Abbott)') }\end{array}$ & 54.6 & 1.0 & 1.0 & - & - & - & - & $\begin{array}{l}\text { y-Scintillation } \\
\text { Spectrometer } 5375 \\
\quad \text { (Packard) }\end{array}$ \\
\hline $\begin{array}{l}\text { Res-O-Mat } \mathrm{Fe}^{50} \\
\text { (Byk-Mallinckrodt) })\end{array}$ & 15.9 & 0.5 & 3.0 & $\begin{array}{c}\text { Tris } 0.05 \\
\quad(8.5)\end{array}$ & - & - & - & $\begin{array}{c}\gamma \text {-Scintillation } \\
\text { Spectrometer 5375 } \\
\text { (Packard) }\end{array}$ \\
\hline
\end{tabular}

1) E. Merck AG (D-61 Darmstadt); $\left.{ }^{2}\right)$ 4.7-diphenyl-1.10-phenanthroline-disulfonic acid (bathophenanthroline); ${ }^{2}$ ) Deutsche Hoffmann-La Roche (D-7887 Grenzach); ') 3-(2-pyridyl)-5.6-bis(4-phenylsulfonic acid)-1.2.4-triazine (ferrozine); 5$)$ Dr. H. Haury (D-8 Munich 23); ? Deutsche Abbott GmbH (D-6507 Ingelheim); ') Byk-Mallinckrodt Chemische Produkte GmbH (D-6 Frankfurt).

Tab. 2

The precision from-day-to-day of various procedures for the determination of the iron binding capacity. $\mathrm{LIBC}=$ latent, TIBC = total iron binding capacity

\begin{tabular}{|c|c|c|c|c|c|c|c|c|c|}
\hline \multirow[t]{2}{*}{ Controlserum } & \multirow{2}{*}{$\begin{array}{c}\text { Transferrin } \\
\text { I }\end{array}$} & \multirow{2}{*}{$\begin{array}{c}\text { Roche } \\
\text { II }\end{array}$} & \multirow{2}{*}{$\begin{array}{l}\text { Haury } \\
\text { III }\end{array}$} & \multirow{2}{*}{$\begin{array}{l}\text { DSA } \\
\text { IV }\end{array}$} & \multirow{2}{*}{$\begin{array}{c}\text { Merckotest } \\
\text { V }\end{array}$} & \multirow{2}{*}{$\begin{array}{c}\text { Ferrozine } \\
\text { VI }\end{array}$} & \multirow{2}{*}{$\begin{array}{c}\text { Irosorb } \\
\text { LIBC }+\mathrm{Fe} \\
\text { VII }\end{array}$} & \multicolumn{2}{|c|}{ Res-O-Mat } \\
\hline & & & & & & & & $\begin{array}{l}\text { TIBC } \\
\text { VIII }\end{array}$ & $\begin{array}{c}\mathrm{LIBC}+\mathrm{Fe} \\
\mathrm{IX}\end{array}$ \\
\hline Seronorm & $\varnothing$ & $\left.92.5^{*}\right)$ & 72.0 & 75.5 & 51.7 & 61.4 & 74.5 & 61.2 & 63.7 \\
\hline \multirow[t]{2}{*}{ Lot No. 117} & & 7.5 & 4.2 & 3.6 & 5.1 & 9.4 & 5.7 & 3.5 & 3.5 \\
\hline & & (11) & (11) & (20) & (12) & $(10)$ & (9) & (10) & (11) \\
\hline Monitrol I & 61.2 & 120.5 & 86.1 & 101.7 & 54.1 & 61.9 & 77.0 & 67.4 & 69.4 \\
\hline \multirow[t]{2}{*}{ Lot No. 114} & 5.8 & 4.6 & 2.7 & 5.7 & 4.1 & 5.0 & 3.7 & 4.1 & 3.2 \\
\hline & (11) & (10) & (9) & (20) & (10) & (9) & (10) & (12) & (11) \\
\hline Hyland & 56.2 & 107.0 & 65.5 & 77.7 & 41.2 & 52.0 & 71.1 & 62.7 & 60.2 \\
\hline \multirow{2}{*}{ Lot. No. RO4 } & 8.2 & 2.4 & 6.0 & 6.9 & 2.6 & 5.3 & 6.3 & 2.7 & 4.9 \\
\hline & (7) & (6) & (6) & (20) & (7) & (5) & (6) & (5) & (6) \\
\hline
\end{tabular}

*) Mean value with coefficient of variation and number of contributing values (in parenthesis).

Tab. 3

Comparison of various methods for the determination of the iron binding capacity in serum samples from unselected patients of a medical polyclinic

\begin{tabular}{|c|c|c|c|c|c|c|c|c|c|}
\hline Method & $\begin{array}{c}\text { Transferrin } \\
\text { I }\end{array}$ & $\begin{array}{c}\text { Roche } \\
\text { II }\end{array}$ & $\begin{array}{l}\text { Haury } \\
\text { III }\end{array}$ & $\begin{array}{l}\text { DSA } \\
\text { IV }\end{array}$ & $\begin{array}{c}\text { Merckotest } \\
\text { LIBC+Fe } \\
\text { V }\end{array}$ & $\begin{array}{c}\text { Ferrozine } \\
\text { LIBC+Fe') } \\
\text { VI }\end{array}$ & $\begin{array}{l}\mathrm{Re} \\
\left.\mathrm{TIBC}^{*}\right) \\
\text { VII }\end{array}$ & $\begin{array}{l}\left.\text { LIBC }+\mathrm{Fe}^{5}\right) \\
\text { VIIII }\end{array}$ & $\begin{array}{c}\text { Irosorb } \\
\text { LIBC+Fe } \\
\text { IX }\end{array}$ \\
\hline $\left.\operatorname{Mean}(\bar{x})^{1}\right)$ & 58.7 & 69.5 & 65.1 & 67.2 & 46.0 & 56.3 & 57.7 & 58.6 & 73.1 \\
\hline n*) & 93 & 83 & 92 & 75 & 65 & 63 & 92 & 86 & 85 \\
\hline$\left.r^{2}\right)$ & - & 0.771 & 0.725 & 0.790 & 0.887 & 0.802 & 0.878 & 0.909 & 0.698 \\
\hline $\begin{array}{l}\operatorname{var}(f j)=s^{2} \\
\text { Standardized }\end{array}$ & 1.2 & 4.7 & 24.9 & 6.2 & 0.9 & 5.0 & 4.2 & 2.3 & 9.8 \\
\hline $\begin{array}{l}\text { variance (\%) } \\
\left.\text { CV }(\%)^{4}\right)\end{array}$ & 0.9 & 3.2 & 11.7 & 3.8 & 0.9 & 3.3 & 4.4 & 2.2 & 8.1 \\
\hline (Reproduction) & 1.9 & 3.1 & 7.7 & 3.7 & 2.0 & 4.0 & 3.6 & 2.6 & 4.3 \\
\hline $\begin{array}{l}\operatorname{var}\left(e_{1}\right) \\
C^{*}(\%)\end{array}$ & - & 55.5 & 77.6 & 57.0 & 21.1 & 50.3 & 18.3 & 16.3 & 52.8 \\
\hline (Regression) & - & 10.7 & 13.5 & 11.2 & 10.0 & 12.6 & 7.4 & 6.9 & 9.9 \\
\hline
\end{tabular}

1) Mean value of all determinations (2n) in $\mu \mathrm{mol} / \mathrm{l}$ (total iron binding capacity). 

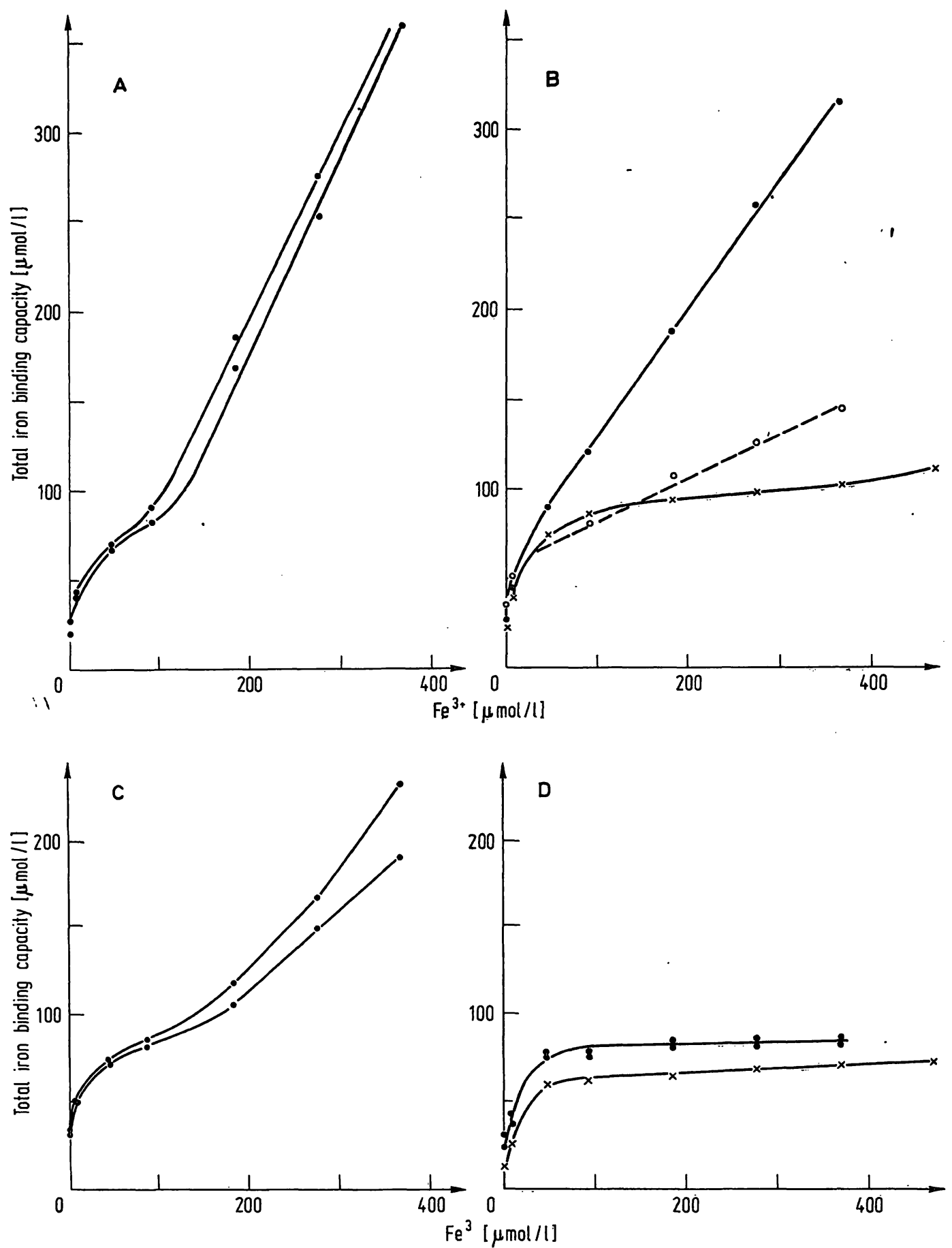

Fig. 1

The influence of the $\mathrm{Fe}^{3+}$ concentration $(200 \mu \mathrm{l}$ serum $+200 \mu \mathrm{l} \mathrm{FeCl}$ solution) on the total iron binding capacity of various control sera. Each point is of the $\mathrm{Fe}^{3+}$ concentration (200 $\mu$ serum ${ }^{2} \mathrm{O}^{\mu} \mathrm{FeCl}_{3}$ solution) on the total iron binding capacity of various control sera.

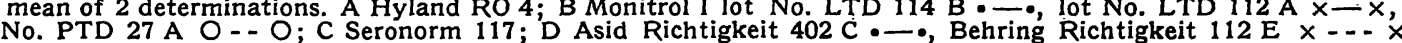

below the reference procedure must be rejected. If the same value is found for an indirect and the direct determination of the total iron binding capacity the acceptance of this indirect method must be decided individually. As long as the clinical significance of the non-transferrin proteins binding iron ions is unknown, we prefer to include this percentage. For the binding of $\mathrm{Fe}^{3+}$ ions we, therefore, use an iron concentration $(90 \mu \mathrm{mol} / \mathrm{l})$ at which the plateau part of the saturation curve begins in human sera, and which is close to that $(81 \mu \mathrm{mol} / \mathrm{l})$ proposed by Grovannielio and PeCCI (9).
With regard to the fact that quite different techniques were applied, the correlation appears acceptable for all methods (Tab. 3 and Fig. 2). The least variance about regression was observed with methods VII and VIII (Tab. 3). All other procedures were comparable concerning $\operatorname{var}\left(e_{i}\right)$ and $C V$.

\section{Hemoglobin interference}

Hemoglobin is reported (11) to increase the value of the total iron binding capacity in colorimetric procedures (Tab. 4). However, this interference is not detected with immunological and radiochemical methods as 
Tab. 4

The influence of hemoglobin on the determination of the total iron binding capacity ( $\mu$ mol/1) of human pool serum by various methods. I A $76 \mathrm{~g} / 1$ hemoglobin stock solution was added to human pool serum to give final hemoglobin concentrations of $0.5,1.5$ and $7.5 \mathrm{~g} / \mathrm{l}$. II $\mathrm{Physiological} \mathrm{NaCl}$ solution $(9 \mathrm{~g} / \mathrm{l})+$ pool serum, III $76 \mathrm{~g} / \mathrm{l}$ hemoglobin solution + physiological $\mathrm{NaCl}$ solution. Each value is a mean of 2 determinations

\begin{tabular}{|c|c|c|c|c|c|c|c|c|}
\hline \multirow[b]{2}{*}{ Sample } & \multirow[b]{2}{*}{$\begin{array}{l}\text { Hemoglobin } \\
\text { concentration }\end{array}$} & \multirow[b]{2}{*}{ DSA 560} & \multirow[b]{2}{*}{ Merckotest } & \multicolumn{3}{|c|}{ Total iron binding capacity $(\mu \mathrm{mol} / \mathrm{l})$} & \multirow[b]{2}{*}{ Irosorb } & \multirow[b]{2}{*}{$\begin{array}{l}\text { Res-O-Mat } \\
\text { TIBC }\end{array}$} \\
\hline & & & & $\begin{array}{c}\text { Roche } \\
\text { diagnostica }\end{array}$ & Haury & Transferrin & & \\
\hline I & 0.5 & 52 & 33 & 62 & 56 & 39 & & 43 \\
\hline II & - & 54 & 33 & 60 & 55 & 39 & 1 & 42 \\
\hline III & 0.5 & $<1$ & $<1$ & 1 & 4 & $<1$ & & 10 \\
\hline I & 1.5 & 55 & 29 & 65 & 81 & 34 & 31 & 44 \\
\hline 111 & 1.5 & $<1$ & $<1$ & 4 & 10 & $<1$ & 6 & 7 \\
\hline I & 7.5 & 64 & & 66 & 96 & 33 & 28 & 42 \\
\hline 11 & - & 54 & & 60 & $80^{\circ}$ & 33 & 28 & 44 \\
\hline IIII & 7.5 & 12 & & 8 & 31 & $<1$ & 14 & 16 \\
\hline
\end{tabular}

shown in experiments where various concentrations of hemoglobin were added to human sera (Tab. 4). In the absence of serum (III in Tab. 4) hemoglobin was precipitated and it apparently absorbed some labelled $\mathrm{Fe}^{3+}$ which led to false values for the iron binding capacity.

\section{Conclusion : :}

Method I (Tab. 2 and 3) determines the transferrin concentration from which the transferrin binding capacity can be calculated. This can be distinguished from the total iron binding capacity. Methods II-IV and apparently method IX determine the total iron binding capacity of human serum (but not that of several control sera). Method VI-VIII yield the total iron binding capactiy minus a small part of unknown origin. The results equal the transferrin binding capacity. At the moment it cannot be decided whether this congruence occurs by chance or whether these methods are specific for the transferrin binding capacity. In comparison with the immunoprecipitation method the Res-O-Mat procedure gave the best results. All other methods (except method V) appeared acceptable for diagnostic purposes. The Haury and Irosorb method had the lowest coefficient of correlation and the highest variance (reproduction). With the mechanization of procedures for immunoprecipitation, these methods are now to be preferred.

\section{References}

1. Stojceskr, T. K., Malpas, J. S. \& Wirts, L. J. (1965), J. Clin. Pathol. 18, 446-452. - 2. Scuro, L. A., Dobrilla, G. Lo Cascio, V., Bosello, O., D’Andrea, F. \& Junesco, A. (1972), Acta Hep. Gastroenterol. 19, 90-98. - 3. VAN DER HeUL, C., vON Eijk, H. G., Wiltink, W. F. \& Lejnse, B. (1972), Clin. Chim. Acta 38, 347-353. - 4. HaECKeL, R. (1973), this j. 11, 301-307. 5. BaMrBaCH, M. N. (1966), Klin. Wochenschr. 44, 1276-1284. 6. Persijn, J. P., van der Slik, W. \& Riethorst, A. (1971),
Clin. Chim. Acta 35, 91-98. - 7. Lehmann, H. \& Huntsman, R. G. (1966), Man's haemoglobins. North-Holland Publishing Co., Amsterdam. - 8. DrABKIN, D. L. \& Austrn, J. H. (1935), J. Biol. Chem. 112, 51-88. - 9. Giovanniello, Th. J. \& Pecci, J. (1972), Stand. Methods Clin. Chem. 7, 127-141. - 10. Ramsay, W. N. M. (1953), Biochem. J. 53, 2227-231. - 11. Goodwin, J. F., Murphy, B. \& Guillemetre, M. (1966), Clin. Chem. 12, $47-57$.
Priv. Doz. Dr. R. Haeckel D-3 Hannover (W. Germany) Karl-Wiechert-Allęe 9 